\title{
COMPENSATION ANALYSIS TO INTENTION TO QUIT BY USING ORGANIZATION COMMITMENT AS THE INTERVENING VARIABLE
}

\author{
Minggar Anggri Prihati \\ minggar_anggri@yahoo.com \\ Hening Widi Oetomo \\ widi2010@yahoo.com \\ Sulistyo Budi Utomo \\ tyo_utomo@stiesiaedu.com \\ National Institute of Public Administration, Republic of Indonesia \\ School of Economics Indonesia (STIESIA) Surabaya
}

\begin{abstract}
ABSTRAK
Tujuan dari penelitian ini adalah untuk menganalisa hubungan langsung antara iklim organisasi dan kompensasi terhadap komitmen organisasi serta menganalisa hubungan tidak langsung antara iklim organisasi dan kompensasi dengan menggunakan karir sebagai variabel antara dengan Komitmen Organisasi. Objek penelitian ini adalah Perusahaan Telekomunikasi Indonesia, dan responden penelitian ini adalah seluruh karyawan di Departemen Teknis. Total populasi di Departemen Teknis adalah 66 karyawan, dengan menggunakan teknik sampel jenuh atau sensus, dimana semua karyawan adalah responden dalam penelitian ini. Teknik analisis dengan menggunakan analisis jalur yang akan menghitung parameter antara hubungan langsung dan tidak langsung. Hasil pertama dari penelitian ini adalah iklim organisasi memiliki hubungan positif langsung yang signifikan terhadap komitmen organisasi sementara kompensasi memiliki hubungan langsung negatif dan tidak signifikan terhadap komitmen organisasi. Hasil kedua penelitian ini adalah iklim organisasi dan kompensasi memiliki hubungan tidak langsung positif dan tidak signifikan terhadap komitmen organisasi melalui karir. Fenomena ini dapat dijelaskan bahwa karyawan di Departemen Teknis adalah sumber daya manusia yang langka di perusahaan telekomunikasi di Indonesia keterampilan mereka dibutuhkan oleh perusahaan.
\end{abstract}

Kata kunci: Kompensasi, iklim organisasi, pengembangan karir, komitmen organisasi, niat untuk keluar

\begin{abstract}
This research was conducted to determine the effect of compensation variable, organizational climate, and career development of the intention to quit with the affective organizational commitment as intervening variables. Research conducted at the respondents PT. X employees in the technical west Surabaya area. Population were all employees amounted to 66 respondents. Analysis techniques used in this study is the analysis of the path (path analysis). Analysis is performed to determine the influence of compensation, organizational climate, and career development of the intention to quit directly or indirectly through affective organizational commitment. Results of analysis showed that the compensation, organizational climate, and career development is significantly negative effect on intention to quit. Compensation, organizational climate, and career development is significantly positive influence on organizational commitment to career development factors as factors that have the greatest influence on organizational commitment. The analysis also points to the results that the organization's commitment is a factor that has the greatest influence on intention to quit.
\end{abstract}

Keywords: Compensation, organizational climate, career development, organizational commitment, intention to quit

\section{INTRODUCTION}

The competent human resources in the field of telecommunication especially technical are still rare in Indonesia. Because of that, employee who has this skill is very valuable for the telecommunication company where they work. In telecommunication business, companies must be ready to 
face the fast moving advance technology and to apply it to their services. In the market competition they must always advance than the competitors (Harvey et al., 2008). This demand is also applied for the new companies, because of that reason they must have human resources who have the minimum of an equal skills with the competitors. This is the reason that they must have ready to work human resources. It will take longer time to recruit. The current trend is to hijack a competent employee from the competitors who has skills and ready to work (Mitchell et al., 2001).

This strategy of hijacking an experienced employee from competitors will be interrupting the companies, especially in the companies' activities. A company's employee who has been hijacked by the competitors must be worry since they will compensate more than the previous company they work at in the form of higher salary, and higher position. These things will make an experienced employee to quit to another company which is giving better job satisfaction (Schwepker, 2001). The compensation, based on Hay's survey found that telecommunication sector is one of sectors with the promising salary. Beside the salary, the companies in this sector are also giving away bonuses. Based on the survey in the year of 2006 the amount of bonus received by the employees in the telecommunication sector is 2,4 times of the salary, and not including the bonus variable which is 1.5 times of the salary (Hidayat, 2006).

Job satisfactions refer to the general individual character to his jobs. Someone who has high job satisfaction will have positive attitude to his jobs while someone who has low job satisfaction will have negative attitude to his jobs (Cetin, 2006). To create job satisfaction to the employees some factors are needed which are work conditions, co-workers relation, supervising, career development and the salaries in the journal of management. By fulfilling the salary satisfaction, work conditions and career development, so employees' productivity and commitment will increase.

Organizational commitment is the conditions where employees are interested on the purposes, values and organizational goals. The organizational commitment means more than the formal memberships, because of the character to like the organization and the willingness to improve the organization's interest to achieve the goals. Based on that understanding, the organization's commitment includes organizational loyalty, the job involvement and the identification to the values and the goal of the organization (Finegan, 2000). The organizational commitment is more than the passive loyalty to the organization, in another words, the organizational commitment is the active relationship between employee and the company (Kuntjoro, 2009). The intention to quit will tend to be lower from the employee when there is high commitment. The intention to quit is the employees' behavior to be seriously quitting from his job.

PT. $X$ is a company of the infocom (Information and Communication) which provides services and networking. PT. $X$ is also providing non moving cable or fixed wire line, fixed wireless, cellular services, data and internet, interconnection networks, direct or indirect through the subsidiaries. PT. $X$ is one of the most well-known company in Indonesia.

The employee management in the organization is including the career system, compensation, development. If the employees feel their needs are fulfilled that will increase the commitment to the company. Then, the intention to quit level will tend to be low. Technical employees at PT. $X$ are the most valuable intangible assets since the skills are still rare.

From the research background above, then the problems can be identified from this research are:

1. Does the compensation have direct significant effect to the intention to quit? 
2. Does the compensation have indirect significant effect to the intention to quit through organization commitment?

3. Does the organization climate have direct significant effect to the intention to quit?

4. Does the organization climate have indirect significant effect to the intention to quit through organization commitment?

5. Does the career development have direct significant effect to the intention to quit?

6. Does the career development have indirect significant effect to the intention to quit through the organization commitment?

The purposes of this research from the above problems are:

1. To know direct effect of compensation factor to the intention to quit at the employee of Technical Department of PT. X.

2. To know indirect effect of compensation factor to the intention to quit at the employee of Technical Department of PT. $X$ through the organizational commitment.

3. To know direct influence of organizational climate factor to the intention to quit at the employee of Technical Department of PT. X.

4. To know indirect influence of organizational climate factor to the intention to quit at the employee of Technical Department of PT. X through the organizational commitment.

5. To know direct effect of the career development to the intention to quit at the employee of Technical Department of PT. X.

6. To know indirect effect of the career development to the intention to quit at the employee of Technical Department of PT. $X$ through the organizational commit ment.

\section{THEORETICAL REVIEW}

\section{Previous Research}

The research about the Intention to Quit has done by Firth (2004) said that intention to quit is mostly influenced by the job dissatisfaction, less organizational commitment and stress. Supervisor supports is the mediator to influence less effect from the stressor and intention to quit. Monitoring the workloads and the relation of the supervisor and the sub-ordinate not only reduce the stress level but also to increase the job satisfaction and commitment to the company. Manager needs to monitor the intrinsic and extrinsic which cause the employee to have the job satisfaction. By monitoring those things intention to quit and turnover will be reduced. The company will save some money for recruitment.

Another research done by Elangovan (2001) about causal ordering of stress, satisfaction and commitment, and intention to quit using a structural equation analysis and said that there is a strong relationship between job satisfaction and commitment and also there is a reciprocal between commitment and turnover intention.

In his thesis, Gunawan (2008) examine about the effect of ISO 9001:2000 implementation to the intention to quit of the employees through the intervening variables of job satisfaction at PT. Dharma Anugerah Indah and shows that job satisfaction has the significant influence to intention to quit. So that the variable intervening of job satisfaction will be getting stronger as the influence of variable ISO 9001:2000 as the variable of intention to quit.

\section{Basic Theory}

Based on the result of the pre-survey on the employees who resigned, the most influential factors of the employees quit from PT. $X$ are compensation, organizational climate and career development. Employees decide to quit and move to the same industry because the new company gives them what they did not get from PT. $X$. The decision to quit from the job is the desire of the intention to quit.

\section{Intention to Quit}

According to Porter and Steers (in Mobley, 2007) in the process until the 
resignation intention to quit is the logical effect after the dissatisfaction experienced. The resignation decision shows by thinking of quitting from the company which is the next process after the employees' dissatisfaction. Then, intention to quit is the next step, and finally the resignation is the final action.

The level of high job satisfaction related to the low employee turnover (Newstrom, 2007). The employees who have job satisfaction will have less possibility to go to the process of thinking to quit from his job or to announce their intention to quit.

Lum et al. (1998) said that intention to quit is most related variable to explain the turnover behavior. The intention to quit can be measured by 3 components which are:

1. The needs to look for a new job in the same field at another company.

They think another company will give more advantages compare to the current company where they work, can be the main reason for the individual to quit.

2. The needs to look for a new job in the different field.

An individual who thinks that they do not get improvements will try to switch to a different field. An individual doesn't have to learn a new skill, he just looks for a new field with the same skills that he has right now.

3. The needs to look for a new job.

By having many skills will make it easier for someone to look for a new job that he has never done it before.

\section{Organizational Commitment}

Organizational commitment or employee loyalty is the degree where an employee will be on the company's side and has the intention to continue the activities/participate in the organization (Testa, 2001). This commitment is the measurement of the employees desire to stay in the company. This is the reflection of the employees' belief to the mission and the company's goals. The employees are willing to work in order to get the achievement and the willingness to stay in the company. This commitment is strong to the employees who work for longer period of time. Employees who have good record will show the loyalty to the company's policy, and have low turnover (Rowden, 2000).

The organizational commitment shows by 3 characters which are goals, involvements, and the loyalty to the organization (Ivancevich, 2008). The committed employees to the organization will have less possibility to quit from the organization and take another job.

\section{Compensation}

Compensation is total reward given to the employees as a return for their hard work (Burns, 2006). Compensation can be financially or non financially. Good compen sation system will be able to give satisfaction to the employees and will make the company to obtain, to employ and to retain the employees. For the organization, compensation has the important meaning since it reflects the organization effort to retain and to increase the employees' prosperity. The lack of compensation will decrease the job motivation and satisfaction, even causing the employees to quit from the company.

Compensation system is one of the most important potential in order to influence the performance. If the organization neglects the potential, it will cause some personal problems, for example low motivation, low performance, high turnover level, irresponsible behavior, even the employee dishonesty (Bebchuk and Fried, 2003).

\section{Organization climate}

Lussier et al. (2008) said that organizational climate is the relatively enduring quality of the internal environment of the organization perceived by its member. Organization climate can be define as a "measurable, collective perception of organization members about those aspect of their working life that affect their motivation and behaviour". 
Organization climate is employees perception that can be measured about culture, leadership style, structure, and practice, and personal policy from organization (Dutka, 2002). Climate organization is the most important thing because the employees perception about the company is the basic of the employees behaviour development, and the employees attitude will be affected their behavior (Ayers, 2005).

The organization climate is more about depiction of environment, rather than evaluating or show an emotional reaction. organization can run well because the quality of employees been if the employee paid attention and created a good environment where there is no obstacle to work, the employees will give the true value to organization (Ivancevich, 2008).

Ivancevich (2008) define a organization climate as a thing that can't be measured from work environment, that can be feel direct and indirect from employees and affected motivation and behaviour.

\section{Career development}

Career development is the way of organization to attract employees and keeping the talented employees. Career sequence means the employee positions during his life (DeCenzo and Robbins, 2002). Career is sequence of work activity that give smoothness, serenity, in somebody life (Loader, 2009). Career development as a sequence of activity that increase exploration, formation, success, and career fullfillment.

Career development in Gomez (2007) is "An ongoing and formalized effort that focuses on developing enriched and more capable workers". According Mondy "a formal approach taken by the organization to ensure that people with the proper qualification and experience are available when needed" (Walker, 2006). Career development includes all activities that prepare employees for career advancement. All employees within the organization can join the program.

Career development programs can be held by the in-house or outside parties. The program in-house training is usually held by the department and development of human resources. This program can also be held by outside companies, such as organizations engaged in management. Organization is usually an active management conferences, seminars, or any other career development program.

\section{Research Model}

The Research Model as a foundation for preparing the hypothesis in this study, shown in Figure 1.

\section{Hypothesis}

With reference to the formulation of the problem and the results of previous studies, the hypothesis of this research are:

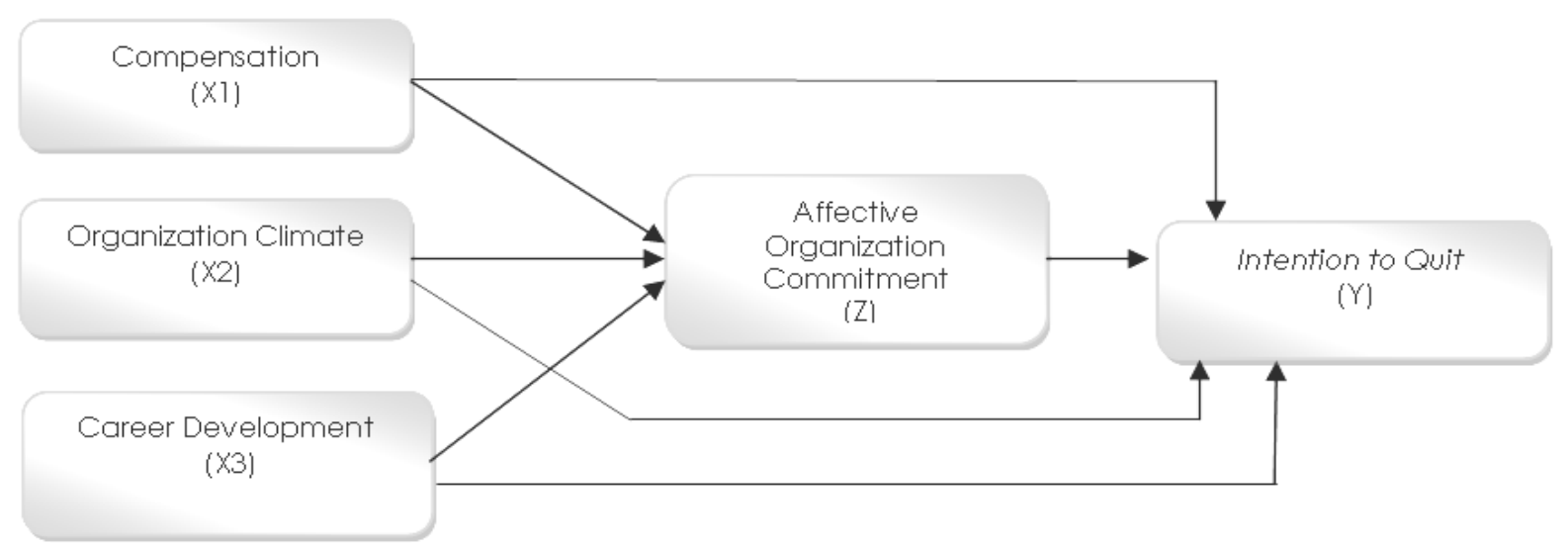

Figure 1

Research Model 
1. Compensation factor has a significant negative effect on intention to quit.

2. Compensation factor has a negative influence significantly to intention to quit through organizational commitment.

3. Organizational climate factors have a significant negative effect on intention to quit.

4. Organizational climate factors have a significant negative effect on intention to quit through organiational commitment.

5. Career development factors have a significant negative effect on intention to quit.

6. Factors of career development have negative influence significantly to intention to quit through organizational commitment.

\section{RESEARCH METHOD}

\section{Population and Sample}

Population is the unit of analysis of its properties will be allegedly. The population in this study amounted to 66 people, which they are all employees who work in the division Infratel PT.X West Surabaya, which is derived from the transmission, switching, local central, central toll, mechanical engineering, and multimedia. This population was chosen with the consideration that the employees who resigned from PT. $X$ are employees of the division Infratel. So it can be concluded that employees who have the intention to quit is an employee at the engineering or the division Infratel. The sampling technique is using census method, where the entire population are respondents. This is done by considering the limited number of existing populations. Type of data in this study is the primary data obtained directly from research subjects through the questionnaire.

\section{Identification Variables and Operational Definition}

Based on the core issues and hypotheses that have been formulated, then the variables will be analyzed are as follows:
1. Independent variables

a. Compensation (X1)

b. Climate organization $(X 2)$

c. Career development (X3)

2. Intervening variable

a. Organizational commitment $(Z)$

3. The dependent variable

a. Intention to quit $(\mathrm{Y})$

\section{Compensation (X1)}

Compensation refers to the total reward obtained by the employees for their performance for the company (Mondy, 2003). Compensation can be either financial or nonfinancial and the indicators are as follows:

a. The employees feel that their salary is acceptable to their work effort.

b. The employees feel that their wage, bonus and commission received is according to their work effort.

c. The employees feel that the social security, insurance, health benefit, onleave paid is according to their work effort.

d. The employees feel comfortable with their work environment.

e. The employees feel that their job will increase their skills and abilities.

$\mathrm{f}$. The employees feel that they being given the responsibilities.

g. The employees feel that their job description is clearly described.

h. The employees feel that there are some rewards on their work efforts.

i. The employees feel that the supervision is competence.

j. The employees feel that their partners are pleasure to work with.

k. The employees feel that the working environment is conducive in order to finish the jobs.

1. The employees feel that their salary is equal to other employees with the same job requirements at other companies.

$\mathrm{m}$. The employees feel that their salary is equal to the level of the seniority. 


\section{Organization Climate (X2)}

The organization climate is how the working environment in the particular company. The organization climate is the employees point of views to the structure, responsibility, reward, risk, warmth, support, identity, standard and conflict that happens in the organization (9 dimensions from Mondy (2003)).

The indicators of organization climates are as follows:

a. The employees feel that the rules in the company is being explained clearly

b. The employees feel that the procedures in the company is being applies firmly.

c. The employees feel that the regulation in the company is always being upgraded as needed.

d. The employees feel that the procedures in the company are being applied flexibly.

e. The employees feel that their rewards on their performance in the company are being accepted according to the work efforts.

f. The employees feel that the punishment in the company is being applied according to the level of the mistakes.

g. The employees feel that the company is given the clear information openly about the risks that will happen to the decision made by the employees.

$h$. The employees feel that they are given the liberty to make a decision on the job.

i. The employees feel that the company is creating the challenges for the employees in achieving the target.

j. The employees feel that the company is appreciating and listening to the different opinions at the work place.

$k$. The employees feel that there are the mutual relationships among other emplo yees at the work place.

1. The employees feel that they are easily working together among other employees at the work place.

\section{Career Development (X3)}

The career development is the conti- nuous formal efforts which focus to the development and enrichment of the employees' ability (Gomez, 2007). The indicators are:

a. The employees feel that they are given the opportunity to join the development programs by the company.

b. The employees feel that the need of the career development is being fulfilled.

c. The employees feel that they are being supported by their superior in order to plan their career development.

d. The employees feel that they are getting all the information needed to join the development program.

e. The employees feel that they have enough information about the career opportunity in the company.

f. The employees feel that they have a particular job, job rotation, and training.

g. The employees do not feel any difficulties in order to get a particular position for the promotion.

\section{Organization Commitment (Z)}

This research is only using the affective commitment, because this research is only targeted to the employees who are still working in the company. The indicators are:

a. The employees feel that they have the same goals, values, and targets of the company.

b. The employees are willing to work hard for the company.

c. The employees are willing to be active/to become the member of the company.

d. The employees are feeling proud to be part of the company.

e. The employees feel that the company's problems are their problems as well.

f. The employees are emotionally bounded to the company.

g. The employees are feeling proud to tell about their company to other people.

$h$. The employees feel that the company has the personal meaning in their life.

i. The employees are having the sense of belonging of the company. 


\section{Intention to quit (Y)}

The intention to quit is the employees' intention to quit/resign from their current jobs (Mobley, 2007). The possibility of the employees to switch and to find another job, or to stay at the current job. The indicators are:

a. There is the intention to quit.

b. The employees want to get a better job than their current job.

c. The employees want to find new job.

d. The employees want to find new job in the same industry.

e. The employees want to find new job in the different field.

f. The employees often late to come to work.

g. The employees often no show at their work place.

h. The employees feel that they cannot work hard.

\section{Data Analysis Technique}

Reliability and validity is an important requirement for the questionnaire. A questionnaire is said to be valid if the question on the questionnaires were able to express something that is measured by the questionnaire. Meanwhile, a questioner said to reliable if the respondent's answer to the question is or is stable over time (Ghozali, 2009). Analysis of the test used in this study is to model path analysis (path analysis). Path analysis is an analysis that is used to explain the causal relationship between one or several variables.

Models path analysis used to analyze pattern relationship between variables with purpose to knowing direct influence and influence indirect set free variable (exogenous) against variable tied (endogenous) (Riduwan and Sunarto, 2007). Path analysis based on calculation strong causal relation between correlation from several variables (Ferdinand, 2002).

\section{ANALYSIS AND DISCUSSION \\ The Coefficient of Path Analysis}

Diagram of test results path analysis and the value of the path coefficient of each variable are presented in Figure 2.

\section{Path Coefficient Analysis of Direct}

Value of the path coefficient is directly shown in table 1 :

Table 1 explains that:

a. Compensation positive effect on affective commitment. Any increase in compensation would cause a change/ increase in affective commitment with regression coefficient of 0,545 . Conversely, any decrease in compensation would cause a decrease in affective commitment amounted to 0,545 .

b. Organizational climate has positive influence on affective commitment. Any increase in organizational climate conditions will cause increased affective commitment to the regression coefficient of 0,395 . Conversely, any reduction in organizational climate will cause a decrease in affective commitment with the regression coefficient of 0,395. Career development has positive influence on affective commitment. Any improvement of career development will lead to increased affective commitment with regression coefficient 0,602 . Conversely, any decline in the condition of career development will cause a decrease in affective commitment with the regression coefficient of 0,602 .

c. Affective commitment negatively affect the intention to quit. Any increase affective commitment will cause a decrease in intention to quit with a regression coefficient of 0,518. Conversely, decreased affective commitment will lead to increased intention to quit with the regression coefficient for 0,518 .

d. Compensation negative effect on intention to quit. Any increase in compensation will cause a decrease in intention to quit with coefficient for 0,278. Conversely, a decrease of compensation will lead to increased intention to quit with a regression coefficient of 0,278 . 


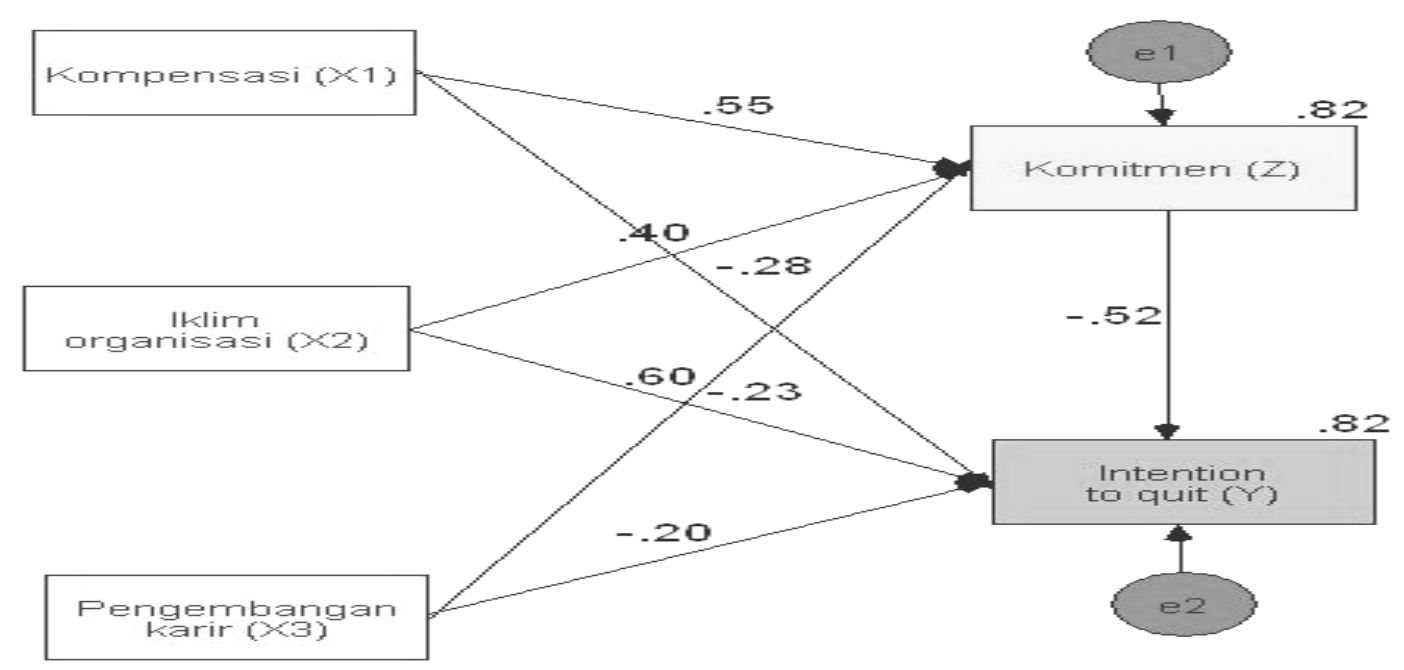

Figure 2

Diagram of the analysis

Table 1

Results of the Standardized Direct Effects

\begin{tabular}{lcccc}
\hline \hline Variabel & $\begin{array}{l}\text { Career } \\
\text { development }\end{array}$ & $\begin{array}{l}\text { Climate } \\
\text { Organization }\end{array}$ & Compensation & $\begin{array}{c}\text { Organization } \\
\text { commitment }\end{array}$ \\
\hline $\begin{array}{l}\text { Organization } \\
\text { commitment }\end{array}$ & 0,602 & 0,395 & 0,545 & 0,000 \\
$\begin{array}{l}\text { Intention to } \\
\text { quit }\end{array}$ & $-0,202$ & $-0,231$ & $-0,278$ & $-0,518$ \\
\hline
\end{tabular}

e. Organizational climate negatively affect the intention to quit. Any increase in organizational climate conditions will cause a decrease in intention to quit with the regression coefficient for 0,231 . In contrast, any decline in organizational climate conditions will lead to intention to quit increases with regression coefficient for 0,231 .

f. Career development negatively affect the intention to quit. Any increase in career development will cause a decrease in intention to quit with a regression coefficient of 0,202. Conversely, the decline of career development will lead to increased intention to quit with a regression coefficient of 0,202 .

The Path Coefficient Analysis Indirectly Value of indirect path coefficients shown in table 2. Table 2 illustrates that the coefficient of the indirect route of compensation to the intention to quit via affective commitment amounted to $-0,282$, as compared with the direct influence that is equal to $-0,278$.

\section{Coefficient Determination}

The coefficient of determination shows the influence of endogenous and exogenous variables on endogenous variables on endogenous variables. The tests showed that the coefficient of determination is presented in table 3 . The amount of compensation effect, organizational climate, and career development of affective commitment $=0,816$, which means that $81,6 \%$ change in the commitment is influenced by three variables (compensation, organizational climate, and career development). 
Table 2

Results of the Standardized Indirect Effects

\begin{tabular}{lcccc}
\hline \hline \multicolumn{1}{c}{ Variabel } & $\begin{array}{l}\text { Career } \\
\text { Development }\end{array}$ & $\begin{array}{l}\text { Organization } \\
\text { climate }\end{array}$ & Compensation & $\begin{array}{l}\text { Organization } \\
\text { commitment }\end{array}$ \\
\hline $\begin{array}{l}\text { Organization } \\
\text { commitment }\end{array}$ & 0,000 & 0,000 & 0,000 & 0,000 \\
$\begin{array}{l}\text { Intention to } \\
\text { quit }\end{array}$ & $-0,312$ & $-0,205$ & $-0,282$ & 0,000 \\
\hline
\end{tabular}

Table 3

Results Squared Multiple Correlations

\begin{tabular}{lc}
\hline \hline Variabel & Estimate \\
\hline $\begin{array}{l}\text { compensation, organizational climate, career development -> } \\
\text { organizational commitment }\end{array}$ & 0,816 \\
$\begin{array}{l}\text { compensation, organizational climate, career development -> } \\
\text { Intention to quit }\end{array}$ & 0,817 \\
\hline
\end{tabular}

While the influence of compensation, organizational climate, and career development of the intention to quit $=0,817$, which means that $81,7 \%$ change in intention to quit was influenced by three variables.

\section{Hypothesis Testing}

Hypothesis test results revealed significant if the probability value $(\mathrm{P})$ was $<0,05$. Significant indicators of whether or not a hypothesis is shown in table 4 .

Probability value of the standardized regression entirely $<0.05$, so the hypothesis test results are significant.

\section{Discussion}

\section{Compensation of Intention to Quit}

Compensation factors have a negative effect on intention to quit. Any increase in compensation would cause a decrease in intention to quit with a regression coefficient of 0278. Conversely, a decrease of compensation will lead to increased intention to quit with a regression coefficient of 0278 . It is consistent with the hypothesis of compensation research namely negative effect on intention to quit. Mean of variable compensation in this study is 3.29 , which is it was lowest among the variables that influence the intention to quit.

In theory, a good compensation system will be able to give satisfaction for employees and enable the company to acquire, hire and retain employees (Mondy, 2003). A good compensation system will be able to lower work performance, work motivation, job satisfaction and employee, it can even cause potential employees left the company. Compensation perceived unfair or less compensated by the company provided employee dissatisfaction will lead to compensation and psychologically will have an impact on lowering the fusion feeling against the company and the declining commitment of employees in the organization. Compensation system in PT.X actually ends meet employees. However, employees feel the compensation they earn is still lower than other similar companies with similar job responsibilities.

Respondents of this study are mostly employees with age above 30 years, which means that they already have families and must meet the needs of their families. With the comparison between PT.X compensation obtained with other similar companies, 
could have PT.X employee who is a potential engineering employees think to get out and move to other similar companies.

\section{Compensation for Intention to Quit through Organizational Commitment}

Effect of indirect compensation to the intention to quit has the negative value of 0,282 . Values influence on intention to quit compensation indirectly through a higher commitment than their indirect value. This means that the compensation would be more affected employees with the intention to quit through organizational commitment.

\section{Climate Organization to Intention to Quit}

Organizational climate factors have a negative effect on intention to quit. Any increase in organizational climate conditions will cause a decrease in intention to quit with a regression coefficient of 0,231 . It is said that the Conversely, any decline in organi- zational climate conditions will lead to intention to quit increases with regression coefficient for 0,231 . This agree with the hypothesis that organizational climate negatively affect the intention to quit. The value of organizational climate influence more to quit is greater than its indirect influence. This means that the organizational climate can directly affect intention to quit without going through organizational commitment, although the organizational climate also has contributed to improve employees' organizational commitment, which commitment to the organization are factors that most influence the intention to quit. If climatic conditions by the employee are not comfortable, it can directly lead to intention to quit on the employees. In theory, organizational climate is important because employees' perception of the company is the basis for the development of the attitude of the employees. If you created a supportive working environment, employees will provide real value to the company
(Ivancevich, 2008). Organizational climate in PT.X been classified as good or employee satisfaction, as seen from the description of variables which are mainly categorized indicators high. Employees feel that their work environment meets the job satisfaction and support the completion of the work.

\section{Climate Organization to Intention to Quit through the Organization Commitment.}

Indirect influence of organizational climate on Intention to quit is negative for 0,205 . In this study, organizational climate has a direct bearing larger $(-0,231)$ than the indirect effect through commitment. But the climate remains organizations have contributed for the increase worker commitment to the organization. It is proved by the positive values of 0,295 on the influence of organizational climate to affective organizational commitment.

\section{Career Development of Intention to Quit}

Career development factors have a negative impact on intention to quit. Any increase in career development will cause a decrease in intention to quit the regression coefficient of 0,202. Conversely, the decline in career development will cause the intention to quit increases with regression coefficient for 0,202. This agrees with the hypothesis that career development negatively affects the intention to quit. Results of analysis showed that career development has an average value (mean) at greater than two other independent variables. This shows that career development is a factor that most affects the commitment and further affects the intention to quit. By increasing employee satisfaction will develop a career, will boost the employees' organizational commitment.

By increasing organizational commitment, it will reduce employees' intention to quit. In theory, career development is the way the company to attract and maintain employees. If employees do not get a chance to develop his career, they will loosen their 
Table 4

Standardized Regression Results

\begin{tabular}{|c|c|}
\hline Effect & $\begin{array}{l}\text { Estimate } \\
\text { Regression }\end{array}$ \\
\hline $\begin{array}{l}\text { compensation }-> \\
\text { organization commitment }\end{array}$ & 0.405 \\
\hline $\begin{array}{l}\text { Organization climate -> } \\
\text { organization commitment }\end{array}$ & 0.289 \\
\hline $\begin{array}{l}\text { Career development -> } \\
\text { organization commitment }\end{array}$ & 0.334 \\
\hline $\begin{array}{l}\text { organization commitment -> } \\
\text { intention to quit }\end{array}$ & -0.547 \\
\hline $\begin{array}{l}\text { compensation -> } \\
\text { intention to quit }\end{array}$ & -0.218 \\
\hline $\begin{array}{l}\text { Organization climate -> } \\
\text { intention to quit }\end{array}$ & -0.178 \\
\hline $\begin{array}{l}\text { Career development -> } \\
\text { intention to quit }\end{array}$ & -0.118 \\
\hline \multicolumn{2}{|c|}{$\begin{array}{l}\text { performance or even resigned from the } \\
\text { company (Mondy, 2003). } \\
\text { Career development of PT.X meets } \\
\text { employee satisfaction. This can be seen in } \\
\text { the descriptions of respondents' answers are } \\
\text { generally categorized high. However, the } \\
\text { promotion opportunities and the lack of } \\
\text { rotation in any position have met the wishes } \\
\text { of employees. }\end{array}$} \\
\hline
\end{tabular}

Career Development of the intention to quit through affective organization commitment.

Career development is indirectly influence the intention to quit through affective organizational commitment is negative for 0,312 . Values influence the career development of the intention to quit indirectly through higher commitment than their indirect value. This means that career development would be more affected employees with the intention to quit through organizational commitment. Total effect of each independent variable is as follows:

- Compensation to $\begin{array}{llr}\text { intention to quit } & = & 0.560 \\ \text { Organization climate } & & - \\ \text { to intention to quit } & = & 0.436\end{array}$

S.E. Estimate Standardized

C.R. $\quad P$

$\begin{array}{llll}0.041 & 0.545 & 9.929 & 0.000\end{array}$

$\begin{array}{llll}0.040 & 0.395 & 7.194 & 0.000\end{array}$

$\begin{array}{llll}0.030 & 0.602 & 10.963 & 0.000\end{array}$

$\begin{array}{llll}0.135 & -0.518 & -4.054 & 0.000\end{array}$

$\begin{array}{llll}0.069 & -0.278 & -3.141 & 0.002\end{array}$

$\begin{array}{llll}0.058 & -0.231 & -3.096 & 0.002\end{array}$

0.055

$-0.202$

$-2.139 \quad 0.032$

- Career development to intention to quit $\quad=\quad 0.514$

The hypothesis of this research is said that all independent variables have a negative effect on intention to quit. Results of analysis show the three independent variablesnamely compensation, organizational climate, and career development negative effect on intention to quit and all independent variables have positive influence in the formation of organizational commitment. Affective organizational commitment negatively affects the intention to quit. Of all the variables that can affect employees' intention to quit in PT.X, compensation factors are factors that have a total impact value is highest among other variables, namely $-0,560$. This indicates that the compensation was formed intention to quit the employee.

\section{CONCLUSION AND SUGGESTION Conclusion}

Based on the results of data analysis with statistical tests, the conclusion can be drawn as follows: 
1. Compensation is significantly negative effect on intention to quit by 0,278 .

2. Compensation for indirect negative impact significantly on intention to quit through organizational commitment for 0,282 .

3. Organizational climate significantly negative effect on intention to quit by 0,231 .

4. Organizational climate has negative indirect significantly to intention to quit through organizational commitment for 0,205 .

5. Career development is significantly negative effect on intention to quit by 0,202 .

6. Career development is not a direct negative impact significantly on the intention to quit through organizational commitment for 0,312 .

The result of analysis with statistical test supports the previous hypothesis which independent variables negatively affect the intention to quit, either directly or indirectly. Based on the path coefficient values obtained from the test path analysis, factors that have the greatest influence on intention to quit employee is compensated. Intervening factors/mediators are also highly influential on intention to quit.

\section{Suggestion}

Based on the calculation of descriptive and hypothesis testing, in which compensation, organizational climate, and career development have a negative impact on employees' intention to quit, then the advice can be given to the company in order to retain employees and increase employee commitment are as follows:

1. The value of total compensation factor to influence intention to quit is $-0,560$. This value represents the highest value compared with other variables, which means that the compensation is the most influence on intention to quit. Therefore, companies should review the balance or harmony between the compensation already awarded the company with the compensation provided by other companies in the field of the same/ similar.
2. Value of the total effect of organizational climate factors on intention to quit is 0,436 . This value represents the lowest value compared with other variables. Value of climate influences intention to quit in the organization of higher value direct than indirect influence. Because of this, companies should give reward and punishment in accordance with employee performance, provide information publicly about the risks of decisionmaking, and provides the opportunity for employees to make decisions in his work.

3. Value of total factors influence the career development of the intention to quit is 0,514 . And career developments of these factors have an influence on the value of the highest organizational commitment than other variables, namely 0,602. Because of this, companies should consider a career employee with the opportunity to employees to develop his career. Also, by responding to the work of employees are by providing an appropriate reward.

\section{REFERENCES}

Ayers, D. F. 2005. Organizational Climate In Its Semiotic Aspect: A Postmodern Community College Undergoes Renewal. Community College Review 33: 1-21.

Bebchuk, L. A. and J. M. Fried. 2003. Executive compensation as an agency problem. Journal of Economics Perspective 17(3): 71-92.

Burns, N. S. K. 2006. The impact of performance-based compensation on misreporting. Journal of Financial Economics $7(9)$ : 35-67.

Cetin, M. O. 2006. The Relationship Between Job Satisfaction, Occupational And Organizational Commitment Of Academics. The Journal of American Academy of Business, Cambridge 8(1): 78-88. 
DeCenzo, D. A and S. P. Robbins. 2002. Human Resource Management. 7thed. Edition. John Wiley \& Sons, Inc. USA.

Dutka, M. A. 2002. The Relationship Between Job Satisfaction And The Organizational Climate For Women Higher Education Administrators At Five Institutions. Retrieved May 1, 2009, From http://escholarship.bc.edu/dissertations/ AAI3043396/

Elangovan, A. R. 2001. Causal Ordering Of Stress, Satisfaction And Commitment, And Intention To Quit: A Structural Equation Analysis. Leadership $\mathcal{E}$ Organizational Development Journal. MCB University Press. http:// www.emerald-library.com/ft accessed by 4 Februari 2009.

Ferdinand, A. 2002. Structural Equation Modeling Dalam Penelitian Manajemen: Aplikasi Model-Model Rumit Dalam Penelitian Untuk Tesis Magister dan Disertasi Doktor. Universitas Diponegoro. Semarang.

Finegan, J. E. 2000. The impact of person and organizational values on organizational commitment. Journal of Occupational \& Organizational Psycho$\log y, 73(2): 149-169$.

Firth, L. 2004. How Can Managers Reduce Employee Intention To Quit?. Journal of Managerial Psychology. Emerald Group Publishing Limited. http://www. emeral-dinsight.com/0268-3946.htm diakses pada 1 April 2009.

Ghozali, I. 2009. Aplikasi Analisis Multivariate dengan Program SPSS. Cetakan Keempat. Badan Penerbit Universitas Diponegoro. Semarang.

Gomez, L. R. 2007. Perceived Organizational Support and Employee Diligence, Commitment, and Innovation. Journal of Applied Psychology 75(1): 51-59.

Gunawan, A. K. 2008. Pengaruh Dampak Implementasi ISO 9001-2000 terhadap Intention to Quit Karyawan melalui Variabel Intervening Kepuasan Kerja di PT Dharma Anugrah Indah. Tesis. Universitas Airlangga. Suabaya.
Harvey, P., K.J. Harris, and M.J. Martinko. 2008. The Mediated Influence of Hostile Attributional Style on Turnover Intentions. Journal of Business and Psychology 2(2): 333-343.

Hidayat, T. 2006. Telekomunikasi: Industri Booming, Gaji pun Hot. SWA 03/XXII/9-22 Februari 2006: 51.

Ivancevich, J. M. 2008. Individual and Group Determinants of Employee Absen- teeism: Test of a Causal Model. Journal of Organizational Behavior 16(5): 469-485.

Kuntjoro, Z. S. 2009. Warta dan wacana: Komitmen Organisasi. http://www. batan.go.id/korpri-serpong/arsip/ wacana_ komitmen.html. Retrieved on July $25^{\text {th }} 2009$.

Loader, T. 2009. Careers Collage: Applying an Art Therapy Technique in Career Development: A Secondary School Experience. Australian Career Practitioner 20(4): 16-17.

Lum, L., J. Kervin, K. Clark, F. Reid \& W. Sirola. 1998. Explaining Nursing Turnover Intent: Job Satisfaction, Pay Satisfaction, or Organizational Commitment. Journal of Organi- zational Behavior (19): 305-320.

Lussier, R. N. 2008. Human Relations in Organizations: A Skill-building Approach. $3^{\text {rd }}$ ed. Irwin USA.

Mitchell, T. R., B. C. Holtom, T. W. Lee, C. J. Sablynski, and M. Erez. 2001. Why people stay: Using job embeddedness to predict voluntary turnover. Journal of Academy and Management Journal 44(6): 1102-1121.

Mobley, W. H. 2007. Intermediate Linkages in the Relationship Between Job Satisfaction and Employee Turnover. Psychological Dimensions of Organizational Behavior. Macmillan Publishing Company Co. New York.

Mondy, R. W. 2003. Further Evidence for the Discriminant Validity of Measures of Organizational Commitment, Job Involvement, and Job Satisfaction. 
Journal of Applied Psychology 76(5): 127133.

Newstrom, J. W. 2007. Commitment to Organizations and Occupations: Extension and Test of a ThreeComponent Conceptualization. Journal of Applied Psychology 78(4): 538-552.

Riduwan and Sunarto. 2007. Pengantar Statistika. Alfabeta. Bandung.

Rowden, R. W. 2000. The Relationship between Charismatic Leadership Behaviors and Organizational Commitment. Journal of Leadership $\mathcal{E}$ Organization Development 21(1): 30-35.
Schwepker Jr, C. H. 2001. Ethical Climate's Relationship to Job Satisfaction, Organizational Commitment, and Turnover Intention in the Salesforce. Journal of Business Research 5(4): 39-52

Testa, M. R. 2001. Organizational Commitment, Job Satisfaction. and Effort in The Service Environment. The Journal of Psychology 135(2): 226-236

Walker, K. 2006. Aiming High: Australian School Leavers' Career Aspirations and The Implications for Career Development Practice. Australian Journal of Career Development 15(2): 53-60. 